\title{
Bağcılıkta terbiye sistemlerinin ekonomik yönden karşılaştırılması: Şanlıurfa ili örneği
}

\author{
Comparison of finishing systems in terms of economic in viticulture: A case study from Şanlıurfa Province in
} Turkey

\author{
Remziye ÖZEL ${ }^{1 \mathscr{O}}$ (D) Baver ESER $^{2}$ iD \\ ${ }^{1}$ Harran Üniversitesi Ziraat Fakültesi Tarım Ekonomisi Bölümü, 63040, Şanlıurfa \\ ${ }^{2}$ Harran Üniversitesi Fen Bilimleri Enstitüsü, Tarım Ekonomisi Anabilim Dalı, 63040, Şanlıurfa
}

MAKALE BILGISI / ARTICLE INFO

\section{Makale tarihçesi / Article history:}

DOI: $10.37908 /$ mkutbd.905730

Geliş tarihi /Received:30.03.2021

Kabul tarihi/Accepted:21.05.2021

\section{Keywords:}

Viticulture, gross profit analysis, cultivation systems, Kruskal Wallis-H, Şanlıurfa.

\footnotetext{
Corresponding author: Remziye ÖZEL

$\varangle$ : rozel@harran.edu.tr
}

\section{ÖZET / A BSTRACT}

Atıf / Citation: Özel R, Eser B, (2021) Bağcılıkta terbiye sistemlerinin ekonomik yönden karşılaştırılması: Şanlıurfa ili örneği. MKU. Tar. Bil. Derg. 26(2) : 365-375. DOI: $10.37908 /$ mkutbd.905730

\section{GíRiş}

Asmanın anavatanı Anadolu'dur. Yapılan bazı çalışmalarda, 1200'ün üzerinde asma çeşidinin varlığına tanık oldukları ve bunların 70-80 kadarının ekonomik olarak üretimde kullanıldığı belirtilmiştir (Anonim, 2003). Asma bitkisi kullanılarak yürütülen üzüm üretim faaliyeti ise bağcılık olarak bilinmektedir. Yabani asma olan Vitis vinifera spp. sylvestris'nın ve kültür asması olan Vitis vinifera L. sativa'nın önemli gen kaynakları arasında Türkiye'de bulunmaktadır (Arroyo-Garcia ve ark., 2006). Türkiye'de Ege Bölgesi bağcılık yapılan alan (\%28.5) ve üretim (\%456) bakımından ilk sırada yer almaktadır. Akdeniz Bölgesi yayla kesimlerinde bağcılığın geliştiği söylenilebilir. Marmara Bölgesi bağcılık üretim faaliyeti 
Trakya'da şaraplık, Anadolu tarafında ise sofralık üzüm çeşitleri daha çok üretilmektedir (Karabat, 2021).

Şanlıurfa ilinde 11137 da alanda bağcılık yapılmakta olup 4753 ton üzüm üretilmektedir. Şanlıurfa ili bağlarının ortalama üzüm verimi $428 \mathrm{~kg} \mathrm{da}^{-1}$ 'dır (TÜiK, 2020).

Güney Doğu Anadolu Projesi kapsamında bölgede sulama olanakları yaygınlaşmakta olup, sulamaya açılan alanlarda sulu tarla tarımına geçilmekte ve bahçe tarımı yapılacak alanlarda ise bağcılık gün geçtikçe daralıp yerini diğer (antepfıstığı vb) üretim faaliyetlerine bırakmaktadır.

Bağcılıkta, farklı terbiye sistemi uygulanmaktadır. Ayrıca, iklim, toprak, çeşit ve ekonomik nedenlerden dolayı bu sistemlerin farklı uygulamaları da mevcuttur (Yüksel ve Ateş, 2021) Türkiye'de son zamanlarda kurulan yeni bağların bir kısmında telli terbiye sistemleri kullanılırken, bağların önemli bir kısmında halen mekanizasyona uygun olmayan terbiye sistemleri yoğunluktadır. Bu durumun, iş gücü masraflarını artırdığı ve geleneksel terbiye sistemlerinden yüksek telli sistemlere geçilmesi gerektiği belirtilmektedir (Karabat, 2021).

Bu araştırmada, Şanlıurfa ilinde kapama bağlarda farklı terbiye sistemleri itibariyle bağcllık faaliyetinin ekonomik faaliyet sonuçları belirlenmiştir. Şanlıurfa ilinde yok olma noktasına gelen bağcılık üretim faaliyetinde, terbiye sistemlerinin üretim maliyetine etkisi belirlenerek terbiye sistemleri ve bağcilığın geliştirilmesi ile ilgili çözüm önerileri geliştirilmiştir.

\section{MATERYAL ve YÖNTEM}

Bu araştırmanın ana materyalini Şanlıurfa illinde bağ üreticileri ile yüz yüze görüşülerek anket yolu ile elde edilen veriler oluşturmaktadır. Bölgede bağcılık ekseriyetle antepfıstığı ya da zeytin tarımında ara tarım biçiminde yapılmaktadır. Çiftçi kayıt sisteminde antepfıstığı ya da zeytin olarak tanımlanmakta olmasından dolayı üretici sayıları ve üretimle ile ilgili sağlıklı veriler elde edilememiştir. Üreticiler evvela saha taramaları ile tespit edilmiş olup daha sonra anket uygulamasına geçilmiştir. İşletmelerin tespiti ve çalışma ile ilgili diğer konularda Şanlıurfa ilinde bulunan kamu kuruluşlarının ve tarım danışmanlarının görüş ve önerilerinden faydalanılmıştır.

Araştırmada esas gaye farklı terbiye sistemlerinin ekonomik analizi olduğu için yalnızca kapama bağ tarımı yapan 54 üreticiye tam sayım yöntemi ile anket uygulanarak veri elde edilmiştir.

Elde edilen verilere bilgisayar ortamında farklı istatistiki yöntemler uygulanmıştır. İşletmelerin mevcut durumlarının ortaya konulmasında tanımlayıcı istatistik yöntemler kullanılmıştır. Frekans, ortalama, yüzde dağııım kullanıımıştır.

Üretim ekonomisi açısından, üreticinin üretime devam edebilmesi için üretimden elde edilen brüt karın üretim faaliyetinin değişen masraflarını karşılayabiliyor olması gerekir. Yani üretici üretim faaliyetini değerlendirirken değişen masraflarını dikkate almaktadır (Aras, 1988).

Araştırma alanında bağların önemli bir kısmının yeni olmaması, üreticinin kendisinin tesis etmemiş olup miras yolu ile intikal etmiş olması tesis dönemi masraflarının üretici üzerinde etkisini azaltmaktadır. Ayrıca işletmelerde birden fazla üretim faaliyetinin gerçekleştiriliyor olması sabit masrafların hesabını ve üretim dallarına dağıtılmasını zor ve sağlıksız hale getirmektedir. Söz konusu bağların tesis dönemi masrafları ile ilgili verilerin elde edilememesine neden olmaktadır. Tüm bu nedenlerden dolayı yıllık bağ tarımsal faaliyeti sonuçları brüt kar üzerinden değerlendirilmiştir.

İşletme başına hesaplanan brüt gelir (brüt kâr) miktarı, işletme başına bağ alanına bölünerek dekara brüt gelir hesaplanmış ve karşılaştırmalarda bu değer kullanılmıştır. Üretim faaliyetinin brüt geliri ya da brüt kârı aşağıdaki formülle hesaplanmıştır.

Brüt Gelir = Brüt Üretim Değeri - Değişen Masraflar Brüt üretim değeri, üretim faaliyetinin asıl ve yan ürünlerinden elde edilen toplam değer olarak tanımlanmaktadır (Karagölge, 1996). Bağcılık faaliyeti için brüt üretim değeri üretilen yaş üzüm ve üzümün işlenmesi ile elde edilen ürünlerin üretim miktarının çiftçi eline geçen fiyatlar ile çarpılarak hesaplanmıştır (Erkuş ve Demirci, 1996).

Araştırmanın ana kütlesi Şanlıurfa ilinde kapama bağcılık yaptığı tespit edilen işletmelerden oluşmaktadır. Çalışmada anket yapılan bazı işletmelerin birden fazla sayıda bağ parseline sahip oldukları ve bu parsellerin benzer özellikler gösterdiği (Toprak yapısı, sulama durumu, eğim, gübreleme, bağın yaşı, üzüm çeşidi vb) belirlenmiştir. Ayrıca aynı işletmenin birden fazla terbiye sistemine yer vermediği belirlenmiştir. Birden fazla parselde kapama bağ tarımı yürütülen işletmelerde, işletmenin ortalama bağ alanına en yakın olan parselin verileri brüt kar analizinde kullanılmıştır.

Ayrıca, değişkenlerin normal dağılımdan gelme durumları incelenirken değişkenlerdeki birim sayılar nedeniyle Shapiro Wilk's' den faydalanılmıştır. ShapiroWilk sınaması nonparametrik bir normallik sınamasıdır. ilk kez 1965 yılında Samuel Shapirove Martin Wilk tarafından denenmiş ve yayınlanmıştır (Shapiro, S. S., and M. B. Wilk. 1965).

Gruplar arası farklılıklar ele alındığında değişkenlerin normal dağılım göstermediği durumda Kruskal Wallis- $\mathrm{H}$ 
Testlerinden yararlanılmıştır. Kruskal Wallis-H Testinde anlamlı farklılıkların görülmesi durumunda ise, gruplar arasında görülen anlamlı farkın kaynağını belirlemek için, Post-Hoc test istatistikleri uygulanmıştır. Post-Hoc Çoklu Karşılaştırma Testi ile aralarında farklııı olan gruplar ortaya konmuştur (Kayri, 2009; Issı, 2019). Sonuçların değerlendirilmesinde güven aralığı \%95 olarak kabul edilmiştir. Bu durumda, anlamlılık düzeyi 0.05 ten küçük olması durumunda gruplar arasında istatistiksel olarak anlamlı bir farklılığın olduğu, aksi durumda istatistiksel olarak anlamlı bir farklılı̆ın olmadığı belirtilmiştir.

\section{BULGULAR ve TARTIŞMA}

Araştırmada, hem idareci hem de girişimci niteliğinde olan çiftçinin, işletme başarısında etkili bir unsur olması nedeniyle üreticilerin yaşı (Karagölge, 1996) ve yenilikleri kabullenme sürecini etkilemesi nedeniyle de eğitim durumu (Lionberger, 1960; Roger, 1983) incelenmiştir. Issletmecilerin ortalama 52.42 yaşında olduğu saptanmıştır (Çizelge 1). Bağcılık üretim faaliyeti ile ilgili olarak yapılan bir çalışmada, üreticilerin ortalama 53 yaşında olduğu belirtilmiştir (Kaymaz, 2019). Siirt ilinde bağcılık işletmelerinde yapılan bir çalışmada, üreticilerin \%36'sının 40-60 yaş grubunda olduğu (Gazioğlu Şensoy ve ark., 2020) ve Şanlıurfa ilinde pamuk üreticisi işletmecilerin \%41.1'inin 38-51 yaş aralığında olduğu belirlenmiştir (IssI, 2019).

Üreticilerin tarımsal üretim faaliyetindeki deneyim süreleri (28.44 yıl) ile bağcılık üretim faaliyetindeki deneyim sürelerinin (28.16 yıl) benzer olduğu saptanmıştır (Çizelge 1 ).

Çizelge 1. Üreticilerin sosyo-demografik özellikleri

Table 1. Socio-demographic characteristics of farmers

$\begin{array}{cccc}\text { Ortalama yaş } & \begin{array}{c}\text { Tarımsal faaliyette bulunma } \\ \text { süresi (yıl) }\end{array} & \begin{array}{c}\text { Bağcılık faaliyetinde bulunma } \\ \text { süresi (yıl) }\end{array} & \begin{array}{c}\text { Yıllık Ortalama } \\ \text { gelir }\end{array}\end{array}$

(TL)

\begin{tabular}{lllll}
\hline Min & 35.00 & 15.00 & 15.00 & 20000.00 \\
Max & 65.00 & 50.00 & 50.00 & 100000.00 \\
\hline Ortalama & 52.42 & 28.44 & 28.16 & 33078.43 \\
\hline
\end{tabular}

Araştırmada incelenen bağcılık işletmelerinde işletmecilerin \%25.00'inin okuryazar ve \%25.00'inin ilkokul düzeyinde eğitim aldığı saptanmıştır. Işletmecilerin \%1.79'unun yüksekokul-üniversite düzeyinde öğrenim gördüğü belirlenmiştir. İşletmecilerin \%3.57'sinin okur-yazar olmadığı tespit edilmiştir (Çizelge 2). Bağcılık işletmelerinde yapılan bir çalışmada, üreticilerin \%12.00'sinin okuryazar olmadığı ve yüksekokul-üniversite düzeyinde öğrenim gören işletmecilerin olmadığı belirtilmiştir (Gazioğlu Şensoy ve ark., 2020). Diğer bir çalışmada ise, konvansiyonel bağcllık üretim faaliyetinde bulunan işletmecilerin $\% 45.00$ 'inin ilkokul \%2.50'inin üniversite düzeyinde eğitim aldıkları belirtilmiştir (Kaymaz, 2019).

Çizelge 2. Incelenen bağcllık işletmelerinde üreticilerin eğitim durumu

Table 2. Educational Satus of producers

\begin{tabular}{lll}
\hline Üreticinin Eğitimi & Kişi & $\%$ \\
\hline Okuryazar değil & 2 & 3.57 \\
Okuryazar & 14 & 25.00 \\
Ilkokul & 14 & 25.00 \\
Ortaokul & 19 & 33.93 \\
Lise & 6 & 10.71 \\
Yüksekokul - Üniversite & 1 & 1.79 \\
\hline Toplam & 54 & 100.00 \\
\hline
\end{tabular}

Araştırmada, incelenen işletmelerde hane halkı genişliğinin 5.02 kişi olduğu belirlenmiştir. Çalışmada belirlenen ortalama hane halkı genişliğinin Tüik (2019) verilerine göre Türkiye (3.35) ile önemli derecede bir farkının olduğu ve Şanlıurfa (5.38) ili ile anlamlı denmeyecek kadar az bir farkın olduğu belirlenmiştir (TÜiK, 2020).

İşletmelerin ancak \%18.51'i bağcılığın yanı sıra diğer tarımsal faaliyetlerde bulunmadığı, önemli bir kısmının ise (\%81.49) esas gelir kaynağının tarım olduğu ve 
bağcılığı diğer tarımsal faaliyetlerine ilaveten yaptığı saptanmıştır.

İşletmelerde mülk arazilerin kullanıldığı ve bağcılık yapılan arazi genişliğinin ortalama 32.64 da olduğu belirlenmiştir. Yapılmış olan bir çalışmada, işletmelerdeki bağlıkların önemli bir kısmının 30 dekar ve daha küçük araziler olduğu belirtilmiştir (Çakır ve ark., 2017).

Bağ üretim faaliyetinde, asmalara uygulanan biçim ve bindi sisteminin birleşimine terbiye sistemi denilmektedir. Bağcılıkta aynı zamanda terroir unsurları arasında yeralan terbiye sistemlerinin tercihinde iklim, toprak yapısı, çeşit, ve sulama olanakları, alet makine kullanımı gibi etmenler önemli rol oynar (Bahar ve ark., 2018). Bağın kapama olup olmaması, bağın büyüklüğü, bağ üretim faaliyetine devam etme nedeni (aile tüketimi veya pazara yönelik olma vb) terbiye sistemleri tercihini etkileyen unsurlar arasındadır.

Goble terbiye sistemi; geleneksel terbiye sistemleri içerisinde yer alır. Türkiye'de en çok kullanılan terbiye sistemlerinden biridir. Gövde üzerinde 3-5 kol bulunur ve omcalar $30 \mathrm{~cm}-100 \mathrm{~cm}$ yükseklikte taçlandırılır. Serpene terbiye sistemi ise goble terbiye sistemi gibi geleneksel terbiye sistemlerinden birisidir. Türkiye'de en çok Güneydoğu Anadolu Bölgesi'nde kullanılır. 2- 3 çubuk ve 18 ile 20 gözden oluşur.

İşletmelerde bağlarda uygulanan terbiye sistemlerinin genel olarak serpene $(\% 50.00)$ ve goble (\%44.44) olduğu belirlenmiştir (Çizelge 3). Şanlıurfa'da üreticilerin bağcılık faaliyetlerini geleneksel yöntemlerle devam ettirmekte olduğu söylenilebilir. Ayrıca bağların ortalama 20.66 yaşında olduğu, herek ve telli terbiye sistemlerinde üretim faaliyetinde bulunulan bağların ise 2 yıllık olduğu saptanmıştır (Çizelge 3). Bu durumda üreticinin terbiye sistemi ile ilgili bir tercihi olmamıştır denilebilir. Bağlarda mevcut terbiye sistemini değiştirme ile ilgili düşüncelerinin olup olmadığı işletmecilere sorulmuş tamamı böyle bir değişikliğe gitmek istemediklerini belirtmişlerdir. Yapılan bir çalışmada, bölgede genel olarak, serpene denilen ananevi terbiye sistemlerinin çoğunlukta olduğu ve goble terbiye sisteminin ise nadir olduğu belirtilmiştir (Kaya, 2015).

Çizelge 3. Bağlarda uygulanan terbiye sistemleri

Table 3. Finishing systems applied in vineyards

\begin{tabular}{cccc}
\hline Terbiye sistemleri & Bağın Yaşı (YıI) & İşletme sayısı & $\%$ \\
\hline Serpene & 21.53 & 27 & 50.00 \\
Goble & 21.64 & 24 & 44.44 \\
Herek & 2.00 & 2 & 3.71 \\
Telli & 2.00 & 1 & 1.85 \\
\hline Toplam & 20.66 & 54 & 100.00 \\
\hline
\end{tabular}

Doğu Akdeniz ve Güneydoğu Anadolu bölgeleri Türkiye'de çekirdekli kuru üzüm üretiminin en fazla yapıldığı bölgelerdir. Horoz Karası bölgenin önemli çekirdekli kurutmalık çeşitleri arasında yer almaktadır (Ünal ve Soltekin, 2018). Şanlıurfa ilinde yürütülen bir çalışmada, üretim yapılan üzüm çeşitler arasında Çiloreş ve Horoz Karası üzüm çeşitleri belirtilmektedir (Bekişli, 2016).

Araştırmada, İşletme bazında tek bir çeşit üzümün üretildiği ve işletmelerin önemli bir kısmının (\%55.56) Çiloreş, \%22.22'sinin ise horozkarası çeşidini üretmekte olduğu saptanmıştır. Ayrıca incelenen bağcılık işletmelerinde var olan çeşidin değiştirilmesi yolu ile değil, yeni bağ kurularak Red Globe çeşidinin üretimine de başlandığı belirlenmiştir (Çizelge 4). Konu uzmanları ile yapılan görüşmelerden, üreticilerin Kızlar Tahtası olarak belirttiği çeşidin esasen Çiloreş çeşidi olduğu ve üreticiler arasında Kızlar Tahtası olarak da adlandırıldığı belirlenmiştir. Üreticilerin İslâhiye olarak adlandırdığı çeşidin ise esasen Horoz Karası çeşidi olduğu belirlenmiştir. Bu durumda araştırma alanında 4 çeşit üzüm üretiminin yapıldığı söylenilebilir. 
Çizelge 4. Bağlarda kullanılan üzüm çeşitleri

Table 4. Grape Varieties used in the vineyards

\begin{tabular}{ccc}
\hline Çeşitler & Iş̧letme sayısı & $\%$ \\
\hline Çiloreş & 30 & 55.56 \\
Horozkarası & 12 & 22.22 \\
Azazi & 7 & 12.96 \\
İslâhiye & 3 & 5.56 \\
Kızlar tahtası & 1 & 1.85 \\
Red Globe & 1 & 1.85 \\
\hline Toplam işletme sayısı & 54 & 100.00 \\
\hline
\end{tabular}

Araştırmada, işletmecilere son yıllarda bağlarında veya bağcılık üretim faaliyetinde yapmış oldukları değişiklikler sorulmuştur. İşletmelerin önemli bir kısmının (\%87.04) bağlarında hiçbir değişiklik yapmadıkları belirlenmiştir. Ayrıca değişiklik yapmayan söz konusu üreticilerin tamamı bağlarındaki terbiye sisteminden ve üretim faaliyeti sonuçlarından memnun olduklarını belirtmişlerdir. Bağcılıkla ilgili değişiklik yaptığını belirten işletmelerin \%12.97'si bağ alanlarında yarıdan fazla azaltmaya gitmiştir. İşletmelerin \%5.56'sı terbiye sistemini değiştirmiştir (Çizelge 5).

Çizelge 5. Üreticilerin son yıllarda bağcılık üretim faaliyeti ile ilgili yaptıkları değişiklikler

Table 5. Changes made by producers in recent years regarding viticulture production activities

\begin{tabular}{ccc}
\hline Değişiklikler & Kişi & $\%$ \\
\hline Alan azaltım & 4 & 7.40 \\
Terbiye sistemimi değiştirdim & 3 & 5.56 \\
Hiçbir değişiklik yapmadım & 47 & 87.04 \\
\hline Toplam & 54 & 100.00
\end{tabular}

Araştırmada, üreticilerin önemli bir kısmının (\%85) bağcılık üretim faaliyeti ile ilgili problemler konusunda bilgi ve destek almadıkları belirlenmiştir. Bilgi desteği alanların ise, devletin tarım teşkilatlarından ve yayım danışmanlarından bilgi edindikleri saptanmıştır. Bölgede üreticiler aynı zamanda Antepfıstığı ve zeytin üretim faaliyetinde bulunmaktadır. Bu ürünlerde iyi tarım uygulamaları yürütüyor olmaları nedeniyle işletmeye gelen tarım danışmanlarından bağcılık üretim faaliyeti ile ilgili sorunlarının çözümünde de destek almaktadırlar. Araştırma alanında bağ üretim faaliyetinde bulunanların hepsinin bağlarda tarımsal mücadele ile ilgili destek almak istedikleri saptanmıştır. Ayrıca budama gibi kültürel işlemler (\%14) ve ürün artışı ile ilgili (\%8) bilgi ihtiyacının olduğu tespit edilmiştir. Çakır ve ark. (2017)'nın bölgede yapmış oldukları bir çalışmada da benzer sonuçlar bildirilmiştir.

\section{Bağcılık üretim faaliyetinde brüt kar analizi}

Araştırmada, incelenen işletmelerde terbiye sistemlerine göre dekar başına değişken masraf unsurları hesaplanmıştır (Çizelge 6). Araştırmada, tam sayım ile anket çalışması yapılmış olup Şanlıurfa illinde sadece 1 işletmede telli terbiye sisteminin uygulandığı belirlenmiştir.
Telli terbiye, goble ve serpene terbiye sistemlerinde sırasıyla 2000, 568.74 ve $427.70 \mathrm{~kg} \mathrm{da}^{-1}$ verim alındığı saptanmış olup terbiye sistemleri verim bakımından karşılaştırıldığında, dekara en yüksek verimin telli terbiye sisteminde alındığı belirlenmiştir. Herek terbiye sisteminde yer alan 2 işletmenin verimi ise oldukça düşük olarak belirlenmiştir (Çizelge 7). Ancak söz konusu işletmelerdeki herek sistemli bağların henüz yeni kurulmuş olduğu ve elde edilen ürünün nişane (işaret) olarak adlandırılan ilk ürün olduğu saptanmıştır. Bu nedenle bu araştırmanın yürütüldüğü dönemde alınan verilerle herek terbiye sisteminin verimi ile ilgili olarak bir sonuç bildirmek sağlıklı olmayacaktır. Taşkın ve Demircan (2014) yaptıkları bir çalışmada, telli ve goble terbiye sistemleri ile bağcılık yapılan işletmelerde verimlerin sırasıyla 1928.50 ve $940.50 \mathrm{~kg} \mathrm{da}^{-1}$ olduğunu belirtmişlerdir. Ayrıca, telli terbiye sisteminde üzüm veriminin goble terbiye sisteminden alınan verimin 2 katı kadar olduğunu saptamışlardır (Taşkın ve Demircan, 2014).

Bağcılık üretim faaliyetinde ortalama değişen masrafın, telli terbiye sisteminde $2243.81 \mathrm{TL} \mathrm{da}^{-1}$, goble terbiye sisteminde $438.79 \mathrm{TL}$ ve serpene terbiye sisteminde $300.69 \mathrm{TL} \mathrm{da}^{-1}$ olarak saptanmıştır. Verimde olduğu gibi dekara değişen masraflar açısından da herek sistemli 
bağlar henüz yeni kurulmuş olduğu için bazı masrafların (sulama, gübreleme, komisyon vb) gerçekleşmemiş olması nedeniyle değişen masraflar düşüktür (Çizelge 6). Incelenen işletmeler arasında telli terbiye sistemindeki söz konusu işletmenin değişken masraflarının diğer terbiye sistemlerini uygulayan işletmelerden daha yüksek olduğu saptanmıştır. Araştırmada, telli terbiye sisteminde sulama ihtiyacının diğer terbiye sistemlerine göre daha fazla olması nedeniyle sulama yapıldığı ve bu durumun maliyetleri artıran bir unsur olduğu belirlenmiştir. Diğer terbiye sistemleri ile bağ tarımı yapanların ise sulama yapmadığı saptanmıştır (Çizelge 6).
Araştırmada, telli terbiye ve goble terbiye sistemlerinde diğer terbiye sistemlerine göre ilaçlama masrafları daha yüksek bulunmuştur. Bu durum brüt karı etkileyen unsurlar arasında yer almaktadır (Çizelge 6). Benzer sonuçları bildiren Kandemir (2013), yürüttüğü bir çalışmada, telli terbiye sistemlerinin bağlarda hastalık etmenlerinin etkinliğini daha da artırdığını belirlemiştir (Kandemir, 2013). Sulamadan dolayı bağın nisbi neminin artması; mantar etmenlerinin (külleme, mildiyö vb) oluşmasına uygun ortamı sağlamaktadır.

Çizelge 6. Terbiye Sistemlerine Göre Toplam Değişken Masrafları (TL da ${ }^{-1}$ )

Table 6. Total Variable Costs by Finishing Systems (TL da-1)

\begin{tabular}{ccccc}
\hline Değişken masraflar $\left(\mathrm{TL} \mathrm{da}^{-1}\right)$ & Serpene & Goble & Herek & Telli Terbiye \\
\hline Ara Sürüm & 54.50 & 91.94 & 36.10 & 50.00 \\
Gübreleme & 1.51 & 1.51 & - & - \\
Kullanılan Gübre & 2.48 & 1.51 & - & 20.00 \\
Illaçlama & 22.72 & 34.61 & 19.27 & 38.33 \\
Kullanılan Illaç & 37.87 & 45.34 & 17.07 & 133.33 \\
Su & 11.26 & 3.93 & - & 41.67 \\
Sulama & - & - & - & 1547.98 \\
Budama & 0.79 & - & 24.39 & - \\
Hasat & 12.65 & 36.12 & 31.22 & 37.50 \\
Pazara Taşıma & 32.05 & 40.30 & 24.39 & 125.00 \\
Komisyon & 124.5 & 183.53 & - & 250.00 \\
\hline Toplam & 300.69 & 438.79 & 96.83 & 2243.81 \\
\hline
\end{tabular}

Araştırmada bağcılık tarımsal faaliyetinin Brüt Kar analizi yapılmış olup sonuçlar Çizelge 7'de verilmiştir. Araştırmada brüt kar; işletmenin üzüm üretim faaliyeti sonucu elde ettiği gayrisafi üretim değerinden üretim faaliyetinde kullanılan değişen masrafların çıkarılması ile bulunmuştur.

Terbiye sistemleri gayri safi üretim değeri bakımından karşılaştırıldığında, dekara en yüksek gayrisafi üretim değerinin telli terbiye sisteminde (3000 TL da-1) olduğu belirlenmiştir. Goble ve serpene terbiye sistemlerinde gayri safi üretim değeri sırasıyla $873.015 \mathrm{TL}^{-1}$ ve 617.59 TL da-1 olarak saptanmıştır (Çizelge 7). Çalışmada, terbiye sistemleri brüt kar bakımında karşılaştırıldığında, dekara en yüksek brüt karın telli terbiye sistemi ile üretim yapan işletmede (756.19 $\mathrm{TL} \mathrm{da}^{-1}$ ) olduğu belirlenmiştir. Dekara brüt kar bakımında telli terbiye sistemini sırasıyla goble (356.305 $\mathrm{TL} \mathrm{da}^{-1}$ ) ve serpene (227.758 TL da-1) terbiye sistemi izlemiştir (Çizelge 7). Incelenen işletmelerde belirlenen brüt karda işletmeler arası farklılığın, öncelikle verim farklılığından kaynaklanmakta olduğu saptanmıştır. Bu çalışmanın sonuçları, bağlarda uygulanan telli terbiye sisteminin goble terbiye sisteminden çok avantajlı olduğunu bildiren Taşkın ve Demircan (2014)'ın sonuçları ile de uyumludur. 
Çizelge 7. İşletmelerde kullanılan terbiye sistemlerine göre brüt kar analizi ( $\mathrm{TL} \mathrm{da}^{-1}$ )

Table 7. Gross Profit Analysis by the finishing System Used in vineyard (TL da ${ }^{-1}$ )

\begin{tabular}{|c|c|c|c|c|}
\hline Brüt Kar Analizi & Serpene & Goble & Herek & Telli Terbiye \\
\hline Üzüm Miktarı (kg da ${ }^{-1}$ ) & 427.70 & 568.74 & 171.43 & 2000.00 \\
\hline Üzüm Fiyatı $\left(\mathrm{kg} \mathrm{da}^{-1}\right)$ & 1.444 & 1.535 & 1.600 & 1.500 \\
\hline GSÜD (TL da $\left.{ }^{-1}\right)$ & 617.598 & 873.015 & 274.288 & 3000.00 \\
\hline Toplam Değişken Masraflar (TL da $\left.{ }^{-1}\right)$ & 389.84 & 516.71 & 152.00 & 2243.81 \\
\hline BRÜT KAR (TL da $\left.{ }^{-1}\right)$ & 227.758 & 356.305 & 122.288 & 756.19 \\
\hline
\end{tabular}

Araştırmada, terbiye sistemlerine bağlı olarak, elde edilen ürünün pazar fiyatında önemli bir farklıı̆ıın olmadığı görülmekle birlikte, serpene terbiye sisteminde üretilen ürünün fiyatının diğer terbiye sistemlerindeki ürün fiyatından daha düşük olduğu saptanmıştır (Çizelge 7). Bu durumda üzüm fiyatları üzerinde terbiye sistemlerinin önemli derecede bir etkisinin olmadığı, fiyatların piyasa koşullarına, üzüm çeşidine ve kalitesine bağı olduğu söylenebilir. Nitekim araştırmada, goble ve herek terbiye sistemi ile üretim yapan işletmelerde Horoz Karası çeşidinin diğer çeşitlere göre daha yaygın olduğu belirlenmiştir.

Tüm tarımsal ürünlerde olduğu gibi, kalite ürünün fiyatı üzerinde ve dolayısıyla brüt kar üzerinde önemli bir faktördür. Bağcılıkta üzüm kalitesinde karşılaşılan problemlerden, yeterli şeker birikiminin sağlanmaması, renklenmede sorun yaşama ve salkım ucunda kurumalar ile terbiye sistemleri arasında istatistiksel olarak anlamlı bir farklılık görülmemiştir ( $p>0.05$ ). Araştırmada üzüm kalitesinde karşılaşılan problemlerden, tanelerde çatlama olması ile terbiye sistemleri arasında istatistiksel olarak anlamlı bir farklılık tespit edilmiştir $(p<0.05)$. Ayrıca, üzüm kalitesinde karşılaşılan problemlerden biri olan hastalıklar ve zararlılardan kaynaklanan salkım çürümeleri ile terbiye sistemleri arasında istatistiksel olarak anlamlı bir farklılık olduğu belirlenmiştir $(p<0.05)$ (Çizelge 8). 
Çizelge 8. Meyve kalitesinde karşılaşılan problemler ile terbiye sistemi arasındaki farklılığa ilişkin Kruskal Wallis H testi sonucu

Table 8.Kruskal Wallis $H$ test result regarding the difference between problems regarding fruit quality and finishing System

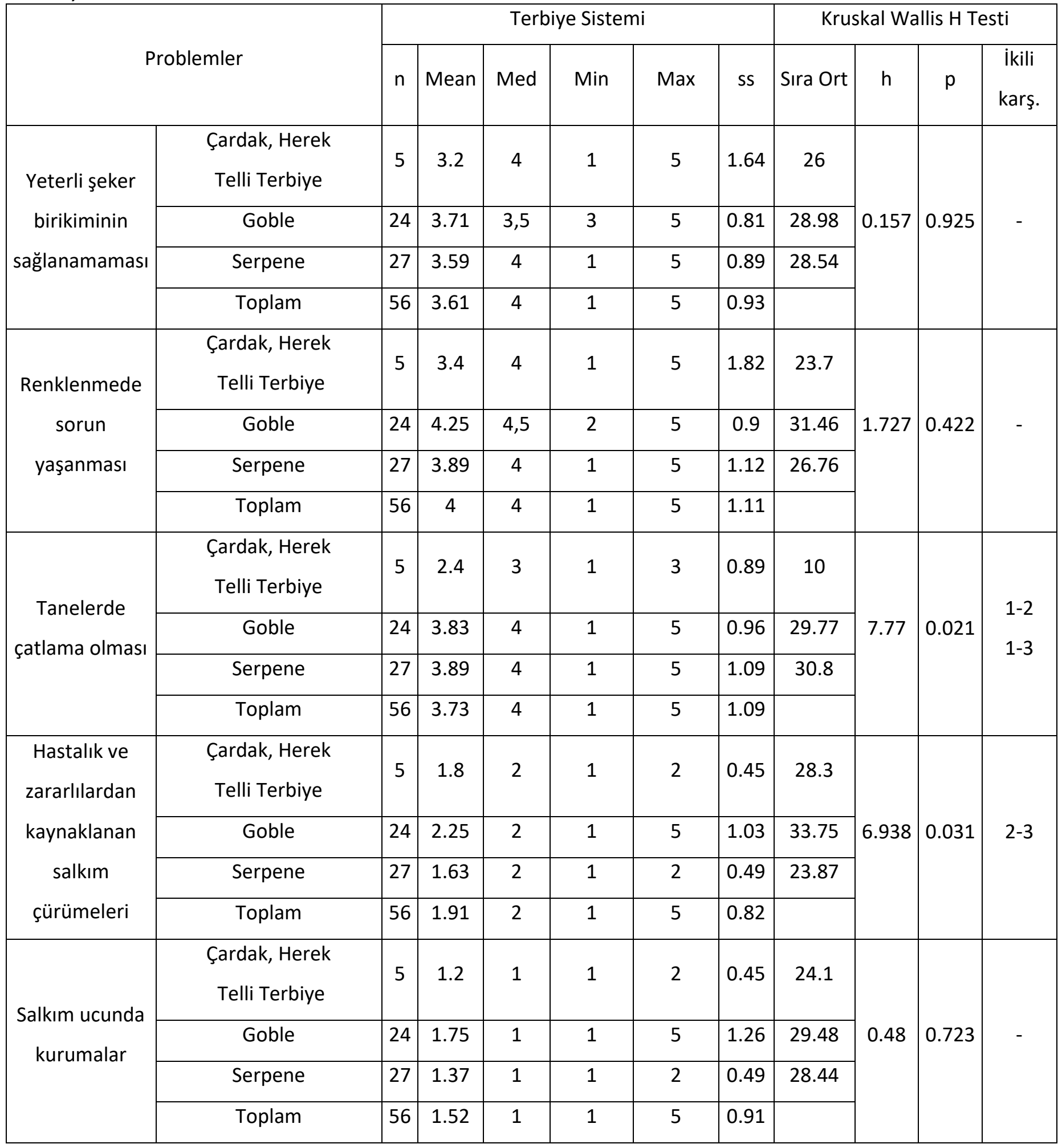

Araştırma yapılan toprakların kireç yönünden orta kireçli, kireçli ile çok fazla kireçli ortamlara sahip olduğu görülmüştür. Incelenen Gaziantep ili Nizip ilçesi zeytin bahçesi topraklarının yarayışlı bor açısından incelendiğinde her iki derinlikteki toprakların (0-30 ve 30-60 cm) yaklaşık \% 90'nın üzerinde yarayışlı bor içeriklerinin çok az va az olmak kaydı ile yetersiz olduğu belirlenmiştir. Bu topraklarda verimi artırmak için 
mutlaka bor gübrelemesi yapılmasının gerektiği söylenebilir.

Sonuç olarak, bölgede bağcılık tarımsal faaliyeti genel olarak geleneksel usulde yürütülmektedir. Modern bağcılık tekniklerine geçişi, üreticinin yaşı, eğitimi, bağcılık üretim faaliyetine bakışı, sulama vb. olanakların varlığı iklimsel koşullar etkilemektedir.

Antepfıstığı bahçelerinde ara tarım olarak bağcılık yapılabilme olanağı kapalı bağ alanlarının cazibesini azaltmıştır. Bağların ara tarım olarak yürütülebilmesi bölgede yüksek terbiye sistemlerine geçilmemesinin nedenleri arasındadır.

İşletmelerde işletmecilerin önemli bir kısmı orta yaştadır. Üreticilerin tarımsal üretim faaliyetindeki deneyim süreleri ile bağcılık üretim faaliyetindeki deneyim sürelerinin birbiri ile uyumlu olduğu saptanmıştır. Bu durumun nedeni bağların ve diğer arazilerin miras yolu ile edinilmesi ve üreticilerin tarımsal üretim faaliyetine geçişle birlikte bağ üretim faaliyetine de başlamasıdır.

Üreticilerin önemli bir kısmının okuryazar veya ilkokul düzeyinde eğitim almış olduğu belirlenmiştir. Araştırmada telli terbiye sistemine geçen üreticinin üniversite mezunu olduğu saptanmıştır. Bu durum eğitimin üretim faaliyetinin geleneksellikten çıkması üzerindeki etkisini ortaya koymaktadır.

Araştırmada üretilen üzüm çeşidi itibariyle yelpazenin dar olduğu, Çiloreş ve horozkarası çeşitlerin yoğunlukta olduğu belirlenmiştir. Bölgeye ait çeşitlerden, bölge iklim ve topak yapısına, sosyo ekonomik koşullarına uygun, pazar değeri yüksek çeşitlerin geliştirilmesi, bağların anaç fidan ve çeşit ıslahının yaygınlaştırılması geliri artıracaktır.

Araştırmada, toplam değişen masraflar, serpene terbiye sisteminde $389.84 \mathrm{TL}$, goblede $516.71 \mathrm{TL}$, herekte 152.00 TL, telli terbiye de 243.81 TL olarak hesaplamıştır. 2017 yılında GDHB tarafından açıklanan verilere göre Şanlıurfa'da Antepfıstığının dekara olan üretim masrafı 300.61TL olarak hesaplanmıştır. Antepfıstığında brüt kar 1610.90 TL olarak belirtilmiş (GDHB, 2018) olup brüt kar bağcılıkta; serpene terbiye sisteminde $227.758 \mathrm{TL}$, goblede $356.305 \mathrm{TL}$, herekte $122.288 \mathrm{TL}$, telli terbiye sisteminde ise $756.190 \mathrm{TL}$ olarak hesaplanmıştır. Bağcılıktan elde edilen gelirin bölgede bağcılığa alternatif olan antepfıstığına göre oldukça düşük olması, bağ alanlarının daralma sebepleri arasındadır.

Telli terbiye sistemi ile yürütülen bağclıktan elde edilen brüt kar (756.190 TL da-1 $)$, yaygın olarak kullanılan serpene ve goble terbiye sistemleri ile elde edilen ortalama brüt karın (292.031,5 TL da-1) yaklaşık 2.6 katı kadardır. Bu durum telli terbiye sisteminde elde edilen verimin yüksekliğinden kaynaklanmaktadır. Araştırma alanında bağ alanlarının miras olarak intikal etmiş olması ve küçük aile işletmeciliği olarak yürütülmesi, modern bağcılığa geçişi zorlaştırmaktadır. Modern bir bağcılıktan elde edilecek ürünün işlenerek pazarlandığı takdirde ne kadar karlı olabileceği ile ilgili tarımsal yayım çalışmaları yürütülmelidir.

Yüksek terbiye sistemlerinde sulama tarımsal mücadele vb. girdi gereksiniminin artması nedeniyle üreticilere üretim faaliyetine özgü ürün tabanlı destek verilmelidir. Bölgede, genellikle bağlarda sulama yapılmamaktadır. Bölgede yürütülen güneydoğu Anadolu Projesinin devreye girmesi ile sulama imkânları artmış ve üreticiler sulamaya ihtiyaç duyulan ve göreceli olarak daha fazla gelir getiren tarım ürünlerinin üretimine yönelmiştir. Tarla tarımına uygun ve sulanabilecek özellik kazanan arazilerde bağlıkların önemi azalmıştır. Bağ üreticilerinin yüksek gelir getirici ve kültürel işlemlerin daha kolay yapılabileceği terbiye sistemlerine geçebilmesi için tesis dönemi hibe programlarının geliştirilmesi ve modern sulama sistemlerinin desteklenmesi gerekmektedir.

İşletmelerin önemli bir kısmının (\%87.04) bağlarda herhangi bir değişiklik yapmadığı ve \%7.40'ının bağ alanlarını daralttığı saptanmıştır. Şanlıurfa ilinde eski bağcılık tekniklerinin (fidan seçimi, terbiye sistemi, diğer kültürel işlemler) devam ettirilmesi, filoksera ile mücadele etme potansiyelini azaltmaktadır. Bağların aşılı-köklü fidanlar kullanılarak yenilenmemesi, bağların gerileme nedenleri arasındadır. Bağ alanlarının hastalık ve zararlılara dayanıklı anaçlar üzerine aşılı fidanlar kullanılarak yenilenmesi konusunda yayım çalışmaları yürütülmelidir.

Bağ alanlarının bir kısmının imara açılması veya bölge halkının bağları kısa süreli tatillerini geçirme amaçlı görmeleri nedeniyle bağlıklarda yerleşim yeri amaçlı kullanım artmıştır. Türkiye' de bağcılık üretim faaliyetinin bölgeler arası ortak özelliği, çok küçük alanlarda ve küçük aile işletmeciliği biçiminde yürütülüyor olmasıdır. Bu durum bağcıllı̆ın gelişmesini, yeniliklere ulaşmayı ve uygulamayı güçleştirmektedir. Bağların miras yoluyla parçalanmasını önleyecek daha etkin düzenlemelere gidilmesi bölge bağlarının sadece kısa süreli tatil alanı olarak görülmeyip ekonomik bir üretim faaliyeti olarak değerlendirilmesini sağlayacaktır.

Tarımsal desteklemeler, çiftçi kayıt Sistemi (Ç.K.S.) verileri ile uygulanmaktadır. Araştırma alanında, bağ alanlarının farklı sebeplerden dolayı kayıt dışı olması (tapu, miras, vb) bağcıllı̆ın geliştirilmesi ile ilgili çalışmaları ve bu konuda kurumlar arası koordinasyonu zayıflatmaktadır. Bağların kayıt altına alınmasına yönelik tedbirler alınmalı ve çeşit kayıtları tutulmalıdır. 


\section{ÖZET}

Amaç: Bu araştırmada, Türkiye'de Şanlıurfa ilinde bağcılıkta serpene, goble, herek ve telli terbiye sistemlerinin ekonomik yönden karşılaştırılması amaçlanmıştır. Ayrıca ürün fiyatını, dolayısıyla brüt karı etkileyen meyve kalitesi ile terbiye sistemleri arasında anlamlı bir farkın olup olmadığı araştırımıştır.

Yöntem ve Bulgular: Araştırmada esas gaye farklı terbiye sistemlerinin ekonomik analizi olduğundan dolayı yalnızca kapama bağ tarımı yapan üreticilere tam sayım yöntemi ile anket uygulanarak veri elde edilmiştir. Ayrıca, değişkenlerin normal dağılımdan gelme durumları incelenirken değişkenlerdeki birim sayılar nedeniyle Shapiro Wilk's' den faydalanılmıştır. Gruplar arası farklılıklar ele alındığında değişkenlerin normal dağılım göstermediği durumda Kruskal Wallis- $\mathrm{H}$ Testlerinden yararlanılmıştır. Yıllık bağ tarımsal faaliyeti sonuçları brüt kar üzerinden değerlendirilmiştir.

Genel Yorum: Bağcılıkta, serpene, goble ve herek terbiye sistemlerine göre telli terbiye sisteminde değişen maliyetlerin daha yüksek olması ile birlikte verimin de yüksek olduğu, dolayısıyla en yüksek brüt karın telli terbiye sisteminden elde edildiği belirlenmiştir. Üzüm kalitesinde karşılaşılan problemlerden, tanelerde çatlama olması ile $(p<0.05)$ ve hastalıklar ve zararlılardan kaynaklanan salkım çürümeleri ile terbiye sistemleri arasında istatistiksel olarak anlamlı bir farklılık olduğu belirlenmiştir $(p<0.05)$.

Çalışmanın Önemi ve Etkisi: Çalışmada toprakların alınabilir bor içerikleri ile sadece silt içeriği arasında negatif önemli bir ilişki belirlenmiştir. Diğer yandan, toprakların tuz içeriği ile kum ve kireç içerikleri arasında negatif, kil içerikleri arasında ise pozitif önemli ilişkiler belirlenmiştir. Ayrıca, toprakların kil içerikleri ile kum, silt ve kireç içerikleri arasında negatif ve silt içeriği ile kireç içeriği arasında ise pozitif önemli ilişkiler belirlenmiştir.

Anahtar Kelimeler: Bor içeriği, zeytin bahçeleri, toprak özellikleri, Gaziantep.

\section{TEŞEKKÜR}

Bu çalışma Şanlıurfa Harran Üniversitesi Bilimsel Araştırma Projeleri Komisyonu Başkanlığı tarafından finansal olarak desteklenen (Proje Numarası: HÜBAK 19112) "Şanlıurfa İlinde Farklı Bağ Terbiye Sistemlerinin Ekonomik Yönden Karşılaştırılması" adlı Yüksek Lisans tezinden üretilmiştir.

\section{ÇIKAR ÇATIŞMA BEYANI}

Yazar(lar) çalışma konusunda çıkar çatışmasının olmadığını beyan eder.

\section{ARAŞTIRMACILARIN KATKI ORANI BEYANI}

Yazarlar makaleye eşit oranda katkı sağlamış olduklarını beyan ederler.

\section{KAYNAKLAR}

Anonim (2003). Üzüm Çalışma Grubu Raporu. Türkiye Ziraat Odaları Birliği http://www.tzob.org.tr/tzob_web/rapor.htm; (01.03.2008).

Aras A (1988) Tarım Muhasebesi, Ege Üniversitesi Ziraat Fakültesi Yayınları, İzmir.

Arroyo-Garcia R, Ruiz-Garcia L, Bolling L (2006) Multiple origins of cultivated grape vine (Vitis vinifera $\mathrm{L}$. ssp. sativa) based on chloroplast DNA polymorphisms. Mol. Ecol. 15: 3707-3714.

Bahar E, Korkutal I, Öner H (2018) Bağcılıkta terroir unsurları. Bahçe 47(2): 57-70.

Bekişli M i (2016) Şanlıurfa ili bağ alanlarının mevcut durumu ve sulama sistemlerinin değerlendirilmesi. Selcuk Journal of Agriculture and Food Sciences, Review Papers, Vol 27 (Özel Sayı) (http://sjafs.selcuk.edu.tr/sjafs/article/view/595)(19 .03.2021)

Çakır A, Odabaşıoğlu M i, İşlek F, Alanko M (2017) Diyarbakır ili Dicle ilçesi bağcılığının mevcut durumu, başlıca sorunları ve çözüm önerileri. Alatarım,- 16(2): 37-46.

Erkuş A, Demirci R (1996) Tarımsal işletmecilik ve planlama. Ankara Üniversitesi Ziraat Fakültesi ders kitabı: 417, s: 158, Ankara Üniversitesi Ziraat Fakültesi Ofset Tesisi Ankara.

Gazioğlu Şensoy R I, Kısaca G, Baş E Ö, Yılmaz Y (2020) Siirt ili ve bazı ilçelerinde mevcut bağclık işletmelerinin yapısal özellikleri ve tarımsal uygulamalara yaklaşımlarının belirlenmesi. Yüzüncü Yıl Üniversitesi Tarım Bilimleri Dergisi 30(2): 289-298.

GTHB 2018 Bitkisel ürün üretim maliyeti. Gıda, Tarım ve Hayvancılık Bakanlığı, Şanlıurfa ilı Müdürlüğü verileri.

Issı S (2019) Pamuk üreticilerinin tarım politikaları karşısındaki tutum ve algıları: Şanlıurfa örneği. (Yayınlanmamış Yüksek Lisans Tezi) Harran Üniversitesi, Fen Bilimleri Enstitüsü, 89 s.,̧̧anlıurfa.

Kandemir Z H (2013) Halfeti yöresinde bağcllıkta geleneksel olarak kullanılan goble ve serpene terbiye sistemlerinin karşılaştırılması üzerine bir araştırma. (Yayınlanmamış Yüksek Lisans Tezi) Harran Üniversitesi, Fen Bilimleri Enstitüsü, Bahçe Bitkileri Anabilim Dalı, $58 \mathrm{~s}$.

Karabat S (2021) Türkiye ve Dünya Bağcılığı (16.03.2021) https://arastirma.tarimorman.gov.tr/manisabagcilik /Menu/26/Genel-Bagcilik 
Karagölge C (1996) Tarımsal işletmecilik-tarım işletmelerinin analizi ve planlanması. Atatürk Üniversitesi Yayınları No:827, Ziraat Fakültesi Yayınları No: 326, Ders Kitapları Serisi No:7, Ziraat Fak. Ofset Tesisi, Erzurum.

Kaya Ö (2015) Dicle ilçesinde geleneksel bağlar ve modern bağların karşılaştırılması. Yüksek Lisans Semineri. Harran Üniversitesi, Fen Bilimleri Enstitüsü, Bahçe Bitkileri Anabilim Dalı, 22 s., Şanlıurfa.

Kaymaz Ö A (2019) Üzüm yetiştiriciliğinde organik ve konvansiyonel üretimin karşılaştırmalı ekonomik analizi. (Yayınlanmamış Yüksek Lisans Tezi) Dicle Üniversitesi Fen Bilimleri Enstitüsü, Bahçe Bitkileri Anabilim Dalı, $88 \mathrm{~s}$.

Kayri M (2009) Araştırmalarda gruplar arası farkın belirlenmesine yönelik çoklu karşılaştırma (POSTHOC) teknikleri. Fırat Üniversitesi Sosyal Bilimler Dergisi 19(1): 51-64.

Lionberger H F (1960) Adoption of new ideas and practices. (Ames: The lowa State University Press.)

Roger E M (1983) Diffusion of inovation. Third Edition. New York: the Free Publication.
Shapiro S S, Wilk M B (1965) An analysis of variance test for normality (complete samples). Biometrika 52: 591-611.

Ünal A, Soltekin O (2018) Dünya kurutmalık üzüm üretimi ve ticareti. / Bahçe 47 (Özel Sayı 1: Türkiye 9. Bağcılık ve Teknolojileri Sempozyumu): 1-9.

Taşkın H, Demircan V (2014) Bağcılıkta telli ve goble terbiye sistemlerinin ekonomik yönden karşılaştırılması: Isparta ili örneği. Süleyman Demirel Üniversitesi Ziraat Fakültesi Dergisi 9(1): 95-110.

TÜiK (2020) i̇statistiklerle aile 2019. (20.02.2021) (https://tuikweb.tuik.gov.tr/)

Yüksel i, Ateş $F$ (2021) Bağcllıkta budama ve terbiye sistemleri. https://arastirma.tarimorman.gov.tr/manisabagcilik /Belgeler/genelbagcilik 